\title{
Nail disorders in patients with chronic renal failure undergoing hemodialysis
}

\author{
Alterações ungueais nos pacientes portadores de insuficiência renal
}

\author{
crônica em hemodiálise
}

\author{
Marcos Antonio Rodrigues Martinez ${ }^{1}$ \\ Vanessa Pedrassi dos Santos ${ }^{3}$ \\ Carlos D'Apparecida Santos Machado Filho ${ }^{5}$
}

\author{
Carla Lobato Gregório ${ }^{2}$ \\ Ronaldo Roberto Bérgamo ${ }^{4}$
}

\begin{abstract}
BACKGROUND: Chronic renal failure affects almost all the systems of the body, including the skin and appendages. The nail disorders most commonly found in patients with chronic renal failure are half and half nails, absent lunula and splinter hemorrhages.

Овјестіves: To evaluate the spectrum and the frequency of nail disorders in patients with chronic renal failure submitted to hemodialysis and compare them with a paired sample from the general population.

Methods: A case-controlled study paired for gender and age was conducted in which nail disorders were investigated in the two groups.

RESUlTS: At least one nail disorder was found in $86 \%$ of the hemodialysis patients and in $75 \%$ of subjects in the control group. Absent lunula (62.9\%) and half and half nails (14.4\%) were more common in the hemodialysis group compared to the control group and this difference was statistically significant $(\mathrm{p}<0.05)$. Longitudinal striae were more common in the control group compared to the hemodialysis group (24.1\%).

Conclusions: Absent lunula and half and half nails were the most common nail disorders found in patients on hemodialysis, corroborating the findings of previous studies. Longitudinal striae were more common in the control group and future studies may clarify whether structural abnormalities such as absent lunula may be related to this finding.
\end{abstract}

Key words: chronic renal failure; kidney dialysis; nail disorders.

Resumo: FundAMENTOS: A insuficiência renal crônica atinge quase todos os sistemas do organismo, inclusive pele e anexos. As alterações ungueais mais observadas nos pacientes com insuficiência renal crônica são: unhas meio a meio, ausência de lúnula e hemorragia em estilhas.

ОвJетrvos: Avaliar o espectro e a frequência de alterações ungueais nos pacientes com IRC, submetidos à hemodiálise (HD), e compará-los com uma amostra pareada da população geral.

MÉTODOs: Realizado um estudo caso- controle, pareado por gênero e idade, onde 2 grupos foram estudados com relação às alterações ungueais presentes.

RESULTADOS: $86 \%$ dos pacientes em HD e $75 \%$ do grupo controle tiveram, pelo menos, uma alteração ungueal. Ausência de lúnula $(62,9 \%)$ e unha meio a meio $(14,4 \%)$ as alterações foram estatisticamente relevantes no grupo $\mathrm{HD}$, em relação ao grupo controle $(\mathrm{p}<0,05 \%)$. Estrias longitudinais foram mais comuns nos controles em relação ao grupo HD $(24,1 \%)$.

CONCLUSÕES: Ausência de lúnula e unha meio a meio as alterações ungueais foram mais encontradas nos pacientes em HD, corroborando com achados relatados, em estudos anteriores. Estrias longitudinais foram mais observadas no grupo controle e estudos posteriores poderão elucidar se alterações estruturais, tal qual a ausência de lúnula, poderiam relacionar-se a este achado.

Palavras-chave: Insuficiência renal crônica; Diálise renal; Doenças da unha

Received on 6.08.2009.

Approved by the Advisory Board and accepted for publication on 13.02.2010.

* Study conducted at the ABC School of Medicine, Santo André, São Paulo, Brazil.

Conflict of interest: None / Conflito de interesse: Nenhum

Financial funding: None / Suporte financeiro: Nenbum

Masters Degree in Dermatology; Assistant Professor, Department of Dermatology, ABC School of Medicine, Santo André, SP, Brazil. Investigator affiliated with the Genetics Laboratory of the Butantan Institute, São Paulo, Brazil.

Currently participating in the residency program in Dermatology of the ABC School of Medicine, Santo André, São Paulo, Brazil.

Currently participating in the residency program in Dermatology of the ABC School of Medicine, Santo André, São Paulo, Brazil.

Head of the Nephrology Department, ABC School of Medicine, Santo André, São Paulo, Brazil.

Professor, PhD, Head of the Dermatology Department, ABC School of Medicine, Santo André, São Paulo, Brazil.

(C)2010 by Anais Brasileiros de Dermatologia

An Bras Dermatol. 2010;85(3):318-23. 


\section{INTRODUCTION}

Chronic renal failure (CRF) results from the generally slow, progressive loss of the excretory function of the kidney. Diabetes mellitus and hypertension are among the principal causes that lead patients to develop CRF and subsequently to a need for dialysis. Other diseases that may affect kidney function include systemic erythematous lupus, amyloidosis, chronic glomerulonephritis and some hereditary diseases (polycystic kidneys). ${ }^{1}$

In normal individuals, the glomerular filtration rate is between 110 and $120 \mathrm{~mL} / \mathrm{min}$, but this rate may fall to 10 or even $5 \mathrm{~mL} / \mathrm{min}$ in patients with advanced $\mathrm{CRF}$ at which time dialysis and kidney transplantation may be indicated. ${ }^{1}$

CRF affects practically all the systems of the body, causing neurological, gastrointestinal, cardiovascular, pulmonary, hematological, endocrine-metabolic and dermatological disorders. ${ }^{1}$ The latter may be due to the condition of the kidneys but may also be due to complications resulting from treatment, which may lead to xerosis, pruritus, hyperpigmentation, calcinosis, bullous dermatosis (pseudoporphyria), perforating dermatosis and nail disorders. ${ }^{2 \cdot 4}$

Nail disorders have been reported to occur in approximately $71.4 \%$ of uremic patients, ${ }^{5}$ the most common disorders being: half and half nails, absent lunula, and splinter hemorrhages. ${ }^{6}$ Half and half nails are found in up to one-third of patients submitted to hemodialysis and represent a marked characteristic of these patients. ${ }^{7}$ In half and half nails, the proximal half is white, while the distal portion is red to brown. ${ }^{6}$

Absent lunula is a condition characterized by absence of the visible portion of the nail matrix, while splinter hemorrhages appear as dark red, filiform, longitudinal lines in the distal region of the nail plate and may also be associated with antiphospholipid antibody syndrome, bacterial endocarditis, trichinosis, onychomatricoma and external trauma. ${ }^{3,8}$

Various studies have reported skin and nail disorders in patients with chronic renal disease undergoing dialysis; however, few of these were controlled studies conducted to compare the prevalence of these disorders in patients undergoing dialysis and in healthy individuals in the general population. ${ }^{6,9,10,11}$
No such controlled study has been performed up to the present time in the Brazilian population.

The objective of this study was to observe and analyze the spectrum and frequency of nail disorders in patients with CRF submitted to hemodialysis and to compare them with a paired sample of individuals selected at random from the general population.

\section{MATERIAL AND METHODS}

A case-controlled study paired for gender and age was conducted in which the presence of nail disorders was evaluated in two groups between August 2005 and July 2007. The sample size of the study group was calculated for a significance level of $5 \%$ and power of $80 \%$. This calculation was performed based on the scarcity of data in the medical literature on the frequency of onychopathies in patients with CRF undergoing hemodialysis.

The first group, referred to as the hemodialysis group, was composed of 97 patients with a clinical and laboratory diagnosis of CRF, who were undergoing hemodialysis at the Nephrology Department of the Teaching Hospitals (Mário Covas State Hospital and Padre Anchieta Teaching Hospital) of the ABC School of Medicine. All the patients included in the study had a history of at least three months of CRF and at least two months of hemodialysis. Of the 97 patients, 60 were men and 37 women. Mean age was 53.75 years (range 21-86 years).

The second group, referred to as the control group, was composed of 108 individuals, 61 men and 47 women, who were randomly selected from among the friends and relatives accompanying patients at the hospital, hospital staff and patients attending the dermatology outpatient department. This group was paired with the hemodialysis group with respect to gender and age (Table 1).

The nails of the patients in hemodialysis and those in the control group were examined and photographed by the investigators using a 6.0 megapixel digital camera. Data on the clinical history, physical and dermatological exams and the medication currently being used by the patients in the two groups were collected using a standard questionnaire. The

TABLE 1: Demographic and clinical characteristics of the study population

\begin{tabular}{lll}
\hline Characteristics & $\begin{array}{l}\text { Patients in Hemodialysis } \\
(\mathbf{n}=\mathbf{9 7})\end{array}$ & $\begin{array}{l}\text { Control Group } \\
(\mathbf{n}=\mathbf{1 1 3})\end{array}$ \\
\hline Age (mean \pm standard deviation) & $53,75 / 14,88$ & $54,42 / 16,62$ \\
Sex (Male/Female)\% & $60 / 3761,9 \% / 38,1 \%$ & $61 / 4756,5 \% / 43,5 \%$ \\
Systemic arterial hypertension & $84(86,6 \%)$ & $26(24,1 \%)$ \\
Diabetes mellitus & $26(26,8 \%)$ & $10(9,3 \%)$ \\
\hline
\end{tabular}


photographs were later analyzed separately by three dermatologists and were considered positive for a disorder when at least two of the three specialists agreed on its diagnosis.

Individuals whose nails were varnished at the time of the evaluation and those in whom it was impossible to evaluate a minimum of 10 out of 20 nails were excluded from inclusion in both the hemodialysis and control groups.

Three patients in the hemodialysis group had had one or more fingers or toes amputated and four had had both feet amputated; however, these patients were not excluded from the study since they had the minimum of ten nails required for evaluation.

The nail disorders evaluated in the two groups were: absent lunula, onycholysis, half and half nails, Beau's lines, chromonychia, nail dystrophy, splinter hemorrhage, melanonychia, leukonychia, longitudinal striae, trachyonychia, koilonychia and Muehrcke's lines.

Nail disorders such as onycholysis, chromonychia, Muehrcke's lines, splinter hemorrhages, koilonychia, half and half nails, leukonychia and absent lunula have been described as being characteristic of patients with CRF and are apparently related to this condition. ${ }^{12}$

Supplementary exams were not performed to confirm the diagnostic hypothesis of onychomycosis (direct mycology and/or culture for fungi) because the majority of the patients on hemodialysis did not give their consent for this procedure.

All procedures were performed and data were collected following prior authorization by the hemodialysis patients and by the individuals in the control group, all of whom signed an informed consent form. These documents were produced and distributed by the principal investigator, who also read the informed consent form aloud and explained the procedures involved in the study to all potential par- ticipants. The present study was duly approved by the internal review board of the ABC School of Medicine.

A descriptive analysis was performed of all the variables in the study. The qualitative variables were presented in terms of their absolute and relative values. The quantitative variables were presented as values of central trend and dispersion. ${ }^{13}$

The chi-square test was used to verify the association between the qualitative values and the study groups. ${ }^{14}$ Student's t-test was used to compare the ages of the participants. ${ }^{14}$

\section{RESULTS}

Overall, $86 \%$ of the patients in hemodialysis and $75 \%$ of the individuals in the control group were found to have at least one nail disorder. The prevalence rates of the different types of nail disorders detected in the patients on hemodialysis and in the controls are shown in Table 2.

The patients on hemodialysis had different rates of various types of nail disorders compared to the control group, absent lunula being the most frequent in hemodialysis patients (62.9\%), followed by half and half nails (14.4\%). Compared to the control group, the hemodialysis patients had a significantly higher rate of these two disorders $(p<0.05)$.

The presence of longitudinal striae was more common in the control group compared to the hemodialysis group and this difference was statistically significant $(\mathrm{p}<0.05)$.

Nail disorders such as Beau's lines, chromonychia, nail dystrophy, splinter hemorrhages, melanonychia, leukonychia and onycholysis were seen in both groups and there were no statistically significant differences between the groups.

Only one case of trachyonychia, one case of koilonychia and one case of Muehrcke's lines

TABLE 2: Prevalence rates of the different types of nail disorders found in hemodialysis patients and in the control group

\begin{tabular}{llll}
\hline Nail disorder & Hemodialysis patients $(\mathbf{n}=\mathbf{9 7 )}$ & Control Group(n= 108) & p-value \\
\hline Absent lunula & $61(62,9 \%)$ & $48(44,4 \%)$ & $<0,05$ \\
Half and half nails & $14(14,4 \%)$ & $0(0 \%)$ & $<0,05$ \\
Onycholysis & $42(43,3 \%)$ & $37(34,3 \%)$ & 0,184 \\
Nail dystrophy & $33(34 \%)$ & $41(38 \%)$ & 0,557 \\
Chromonychia & $17(17,5 \%)$ & $21(19,4 \%)$ & 0,724 \\
Longitudinal striae & $12(12,4 \%)$ & $26(24,1 \%)$ & $<0,05$ \\
Melanonychia & $9(9,3 \%)$ & $9(8,3 \%)$ & 0,811 \\
Splinter hemorrhages & $7(7,2 \%)$ & $6(5,6 \%)$ & 0,626 \\
Beau's lines & $5(5,2 \%)$ & $3(2,8 \%)$ & 0,380 \\
Leukonychia & $4(4,1 \%)$ & $5(4,6 \%)$ & 0,860 \\
Trachyonychia & $1(1 \%)$ & $0(0 \%)$ & 0,279 \\
Koilonychia & $1(1 \%)$ & $0(0 \%)$ & 0,279 \\
Muehrcke's lines & $1(1 \%)$ & $0(0 \%)$ & 0,279 \\
\hline
\end{tabular}


occurred in the group of patients on hemodialysis. These disorders were not found in any of the individuals in the control group.

\section{DISCUSSION}

Chronic renal failure is known to be related to various disorders of the skin and nails. In the present study, $86 \%$ of hemodialysis patients had at least one nail disorder. Studies previously published in the literature have reported values ranging from $52 \%$ to $71 \%{ }^{5,6,9,10,15}$

Absent lunula was the most common nail disorder found in patients on hemodialysis (62.9\%) and there was a statistically significant difference between this group of patients and the control group (Figure 1). Saray et al. ${ }^{9}$ also reported absent lunula as the most frequent abnormality (31.9\%) and suggested that it reflected a variety of conditions in dialysis patients, including metabolic disorders and anemia. ${ }^{9}$ This disorder is more likely to be related to conditions present in chronic renal failure rather than being a result of hemodialysis. The prevalence rate in the present study was much higher than those reported in other recent publications in which rates varied from $16.4 \%$ to $31.9 \%$. ${ }^{6,9,10}$ On the other hand, other studies have reported half and half nails as representing the most common nail disorder in CRF patients on hemodialysis. ${ }^{6,16-18}$ Half and half nails (Figure 2) were the second most common disorder in hemodialysis patients in the present study (14.4\%) and were not found in any individuals in the control group. The etiology of this nail disorder remains unknown. ${ }^{6,19}$ Previous studies have reported that the frequency of half and half nails does not increase with the time of dialysis ${ }^{6,9}$ and that patients with CRF already had the disorder prior to initiating hemodialysis. These investigators believe that the disorder may be related to the

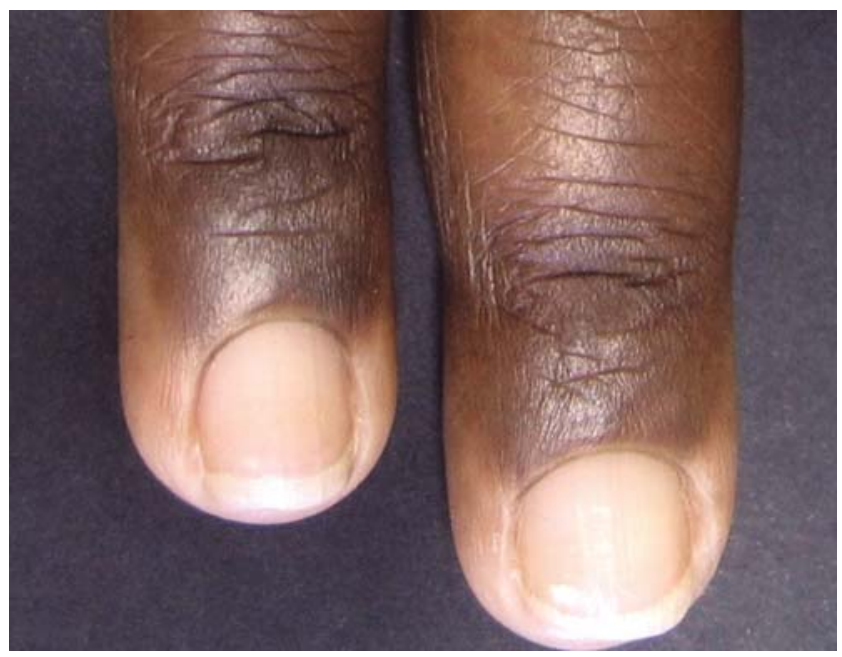

FigURE 1: Absent lunula in a hemodialysis patient

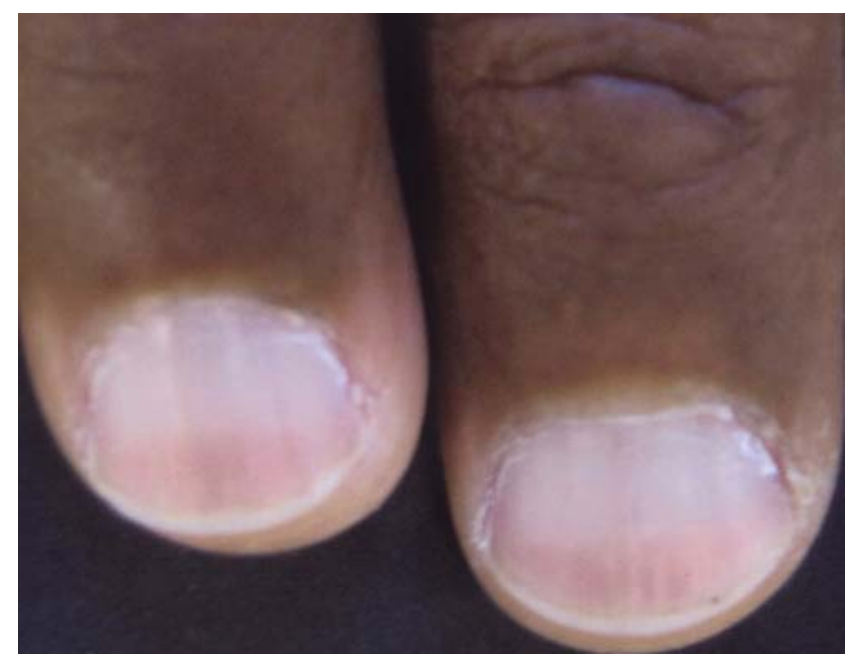

FIGURE 2: Half and half nail in a hemodialysis patient

uremia caused by CRF. ${ }^{6}$ In other publications, the rates of half and half nails varied from $7.7 \%$ to $50.6 \%$. $6,9,10,16,18,19$ Kidney transplant may reduce the rates of this nail disorder. ${ }^{9}$ In 1982, Lubach et al. ${ }^{19}$ noted that half and half nails completely disappeared 2-3 weeks after successful kidney transplant, and Bencini et al. ${ }^{16}$ reported no cases of half and half nails in a group of 105 patients who had been submitted to kidney transplant. ${ }^{9}$ Longitudinal striae are indentations or projections on the surface of the nail plate resulting from trauma, physiological alterations or as a consequence of diseases such as lichen planus, rheumatoid arthritis, Darier's disease, peripheral vasculopathies and genetic abnormalities (Figure 3). They may also occur as a result of tumors situated close to the region of the matrix that exert pressure on it, leading to nail plate surface disorders. ${ }^{12,20}$ In the present study, this disorder was statistically more common in the control group compared to the hemodialysis group $(\mathrm{p}<0.05)$.

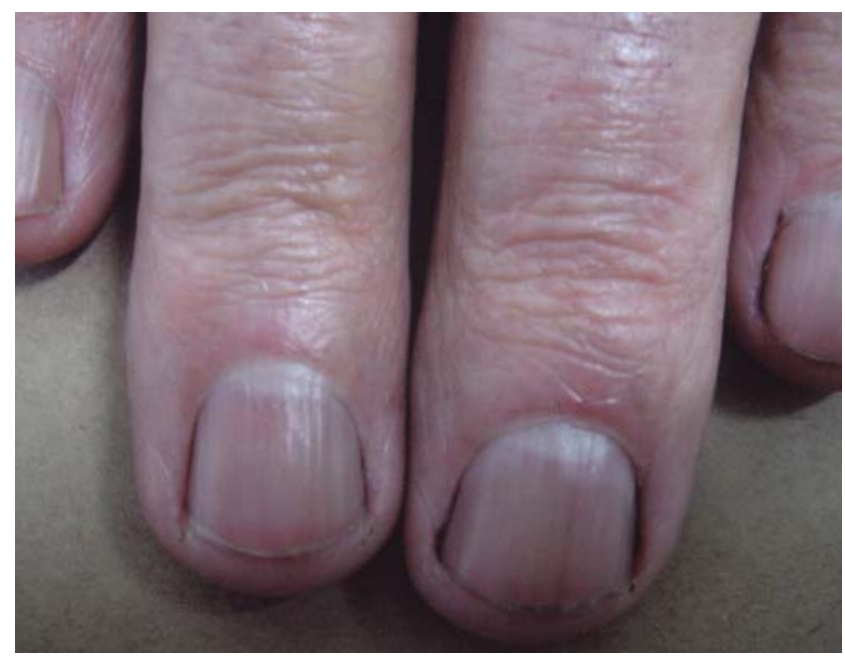

FIGURE 3: Longitudinal striae in an individual in the control group 
The fact that longitudinal striae were not found in the hemodialysis group may be related to the partial absence of the proximal nail matrix (absent lunula), which may lead to the formation of abnormalities in the composition and structure of the nail plate, leaving it unresponsive to trauma. No previous study has reported an absence of longitudinal striae in hemodialysis patients; therefore, further studies should be conducted to evaluate the structure of the proximal nail matrix, keratinocytes and the composition of the nail plate in patients with CRF on hemodialysis and in the general population. Such studies are vital in order to clarify possible causes of this disorder.

Some nail disorders such Beau's lines, onycholysis, chromonychia, nail dystrophy, splinter hemorrhages, melanonychia and leukonychia were seen in both groups and there were no statistically significant differences between the two groups.

Among the drugs used by the patients, the only one that could have been associated with nail disorders is captopril. Captopril has been described as being capable of inducing reversible onycholysis. ${ }^{12,21}$ There has been a report of a lichenoid skin eruption with alopecia, ageusia and nail dystrophy with lichen planus-like features in a patient with renal failure treated with captopril.

Only one case of trachyonychia, one of koilonychia and one of Muerhrcke's lines occurred in the group of hemodialysis patients. These disorders were not found in any of the individuals in the control group.

\section{CONCLUSIONS}

Absent lunula and half and half nails were the nail disorders most commonly found in this sample of Brazilian hemodialysis patients. These disorders were more common in the hemodialysis group compared to the control group and this difference was statistically significant $(\mathrm{p}<0.05 \%)$, corroborating findings reported from other previous studies.

The presence of longitudinal striae was more common in the control group compared to the hemodialysis group and this difference was statistically significant $(p<0.05)$. Further studies should be conducted to clarify whether structural disorders such as absent lunula may be directly related to this relevant finding. 


\section{REFERENCES}

1. Luke RG. Insuficiência renal crônica. In: Ausiello D, Goldman L. Cecil - Tratado de Medicina Interna. 20 ed. Rio de Janeiro: Guanabara Koogan; 2001. p. 632-40.

2. Robinson-Boston L, DiGiovanna JJ. Cutaneous Manifestations of end-stage renal descase. J Am Acad Dermatol. 2000;43:975-86.

3. Clayton BD, Jorizzo JL, Sherertz EF. Alterações cutâneas nos distúrbios renais. In: Fitzpatrick - Tratado de Dermatologia. 5 ed. Rio de Janeiro: Livraria e Editora Revinter; 2005. p. 1930-3.

4. Welter EQ, Bonfá R, Petry V, Moreira LL, Weber MB. Relação entre grau de prurido e qualidade de vida de pacientes em hemodiálise. An Bras Dermatol. 2008;83:137-40.

5. Altmeyer P, Kachel HG, Junger M, Koch KM, Holzmann H. Skin changes in long-term dialysis patients. Hautarzt. 1982;33:137-42.

6. Dyachenko P, Monelise A, Shustak A, ZivM, Rozenman D. Nail Disorders in patients with chronic renal failure and undergoing haemodialysis treatment: a case control study. J Eur Acad Dermatol Venereol. 2007;23:340-4.

7. Headley C, Wall B. End stage renal disease associated cutaneous manifestations in haemodialysis population. Nephrol Nurs J. 2002;29:525-7.

8. Tosti A, Piraccini BM, Chiacchio N. Doença das unhas: clínico e cirúrgico. São Paulo: Luana Livraria Editora; 2007.

9. Saray Y, Seçkin D, Güleç AT, Akgün S, Haberal M. Nail disorders in hemodialyses patients and renal transplant recipients: a case control study. J Am Acad Dermatol. 2004;50:197-202.

10. Tercedor J, Hernandez BL, Rodenas JM. Nail diseases in hemodialysis patients: case-control study. $\mathrm{Br} \mathrm{J}$ Dermatol. 2001;144:415-48.

11. Salem A, Al Mokadem S, Attwa E, Abd El Raoof S, Erbrahim HM, Faheem KT. Nail changes in chronic renal failure patients under haemodialysis. J Eur Acad Dermatol Venereol. 2008;22:1326-31.

12. Tosti A, Baran R, Dawber RPR. The Nail in Systemic Diseases and Drug-induced Changes. In: Baran R,
Dawber RPR, ed. Diseases of the nails and their management. 2nd ed. London: Blackwell; 1994. p. 3580, 175-261.

13. Callegari-Jacques SM. Bioestatística: Princípios e Aplicações. Porto Alegre: Ed. Artmed; 2003.

14. Spiegel S. Estatística não paramétrica. São Paulo: Editora McGraw-Hill; 1981.

15. Pico MR, Lugo-Somolinos A, Sanchez JL, BurgosCalderon R. Cutaneous alterations in patients with chronic renal failure. Int J Dermatol. 1992;31:860-863.

16. Bencini PL, Montagnino G, Citterio A, Graziani G, Crosti C, Ponticelli C. Cutaneous abnormalities in uremic patients. Nephron. 1985;40:316-321.

17. Kint A, Bussels L, Fernades M, Ringoir S. Skin and nail disorders in relation to chronic renal failure. Acta Derm Venereol (Stockholm). 1974;54:137-140.

18. Stewart WK, Raffle EJ. Brown nail bed arcs and chronic renal disease. Br Med J. 1972;1:784-786.

19. Lubach D, StrubbeJ, SchmidtJ. The half and half nail phenomenon in chronic hemodialysis patients. Dermatologica; 1982;164:350-353.

20. Mendonça IRSM, Azulay RD. Afecções das unhas. In: Dermatologia Azulay \& Azulay, 4a Edição. GuanabaraKoogan, Rio de Janeiro; 2006. p. 649-666. 19.

21. Brueggemeyer C, Ramirez G. Onycholysis associated with captopril. Lancet. 1984;1352-3.

22. Smith AJ, Hoorntje SJ, Donker AJM. Zinc deficiency during captopril treatment. Nephron. 1983;34:196-7.

23. Kurban MS, Boueiz A, Kibi AG. Cutaneous manifestations of chronic kidney disease. Clin Dermatol. 2008;26: 255-64.

MAILING ADDRESS / ENDEREÇO PARA CORRESPONDÊNCIA:
Marcos Antonio ROdrigues Martinez
Rua Itapura 300 cj. 301
O3310 OOO, São Paulo, SP, Brasil
Phone./fax: 551120938873 55-11-2093-8873.
e-mail: marcosmartinez@uol.com.br

MAILING ADDRESS / ENDEREÇO PARA CORRESPONDENNCIA:

Marcos Antonio Rodrigues Martinez

Phone./fax: 551120938873 55-11-2093-8873.

e-mail:marcosmartinez@uol.com.br

How to cite this article/Como citar este artigo: Martinez MAR, Gregório CL, Santos VP, Bérgamo RR, Machado Filho CDS. Nail disorders in patients with chronic renal failure undergoing hemodialysis. An Bras Dermatol. 2010;85(3):318-23. 